\author{
Sii IICET \\ Dipublikasikan oleh: \\ Indonesian Institute for Counseling, Education and Therapy (IICET)
}

\title{
The concept of student interpersonal communication
}

\author{
Mufadhal Barseli ${ }^{1}$, Kristinus Sembiring ${ }^{2}$, Ifdil Ifdil ${ }^{3}$, Linda Fitria ${ }^{4}$ \\ ${ }^{1,4}$ Universitas Putra Indonesia " YPTK" Padang, ${ }^{2}$ Universitas Katolik Widya Mandira, ${ }^{3}$ Universitas Negeri \\ Padang
}

\begin{abstract}
Interpersonal communication skills are one competency of students to interact with others. Students who experience problems in interpersonal communication will be hampered in the process of developing creativity and increasing their academic achievement at school. This shows the need for efforts by counselors to develop the counseling service practices to increase students' understanding of the importance of interpersonal communication and the factors that influence low interpersonal communication skills. This paper will introduce the basic concepts of interpersonal communication including; the concept interpersonal communication, the characteristics of interpersonal communication, the importance of interpersonal communication, interpersonal communication criteria, factors that effect interpersonal communication, the process of interpersonal communication, the purpose of interpersonal communication and, communication this can a reference.
\end{abstract}

Keywords: Interpersonal communication

\section{PENDAHULUAN}

Kehidupan manusia tidak dapat dilepaskan dari proses komunikasi, baik itu komunikasi yang bersifat verbal maupun non verbal. Proses komunikasi terjadi dalam berbagai konteks interaksi kehidupan manusia itu sendiri mulai dari komunikasi yang sifatnya interpersonal, kelompok, organisasi, dan komunikasi yang bersifat massal.(Bernard Berelson dalam Riswandi, 2013;Romli, K., \& Si, M. 2017) mendefinisikan bahwa komunikasi interpersonal adalah suatu proses penyampaian informasi, gagasan, emosi, potensi diri melalui simbol-simbol, kata-kata, dan gambar-gambar yang bertujuan untuk mencapai tujuan bersama. Selanjutnya (Ulfah, F. 2013; Suciati 2015) menyatakan bahwa komunikasi interpersonal sangat penting bagi manusia, seperti bagi siswa untuk mengungkapkan ide-ide atau gagasannya ketika proses pembelajaran berlangsung di dalam kelas.

Secara luas DeVito dalam Suciati, 2015; Gunawati, R. 2005) menyatakan bahwa komunikasi interpersonal merupakan suatu proses penyampaian pesan oleh satu orang dan penerimaan pesan oleh orang lain atau sekelompok kecil yang berbentuk tingkah laku baik secara verbal maupun non verbal dengan berbagai dampaknya serta peluang untuk memberikan umpan balik dalam waktu segera. Pentingnya komunikasi interpersonal bagi individu dalam berinteraksi, Mulyana (dalam Suryanto 2015) berpendapat bahwa individu yang tidak pernah melakukan komunikasi interpersonal dengan individu lain dapat dipastikan bahwa individu tersebut akan mengalami hambatan dalam proses perkembangannya karena tidak sempat menata dirinya secara mental dalam lingkungan sosial yang dapat membentuknya menjadi seorang pribadi yang cakap, kreatif dan inovatif. Sejalan dengan pendapat Mulyana tersebut, Zimbardo (dalam Riswandi, 2013) menyatakan idenya bahwa individu yang mengalami kurang komunikasi secara interpersonal disebut dengan istilah anonimitas (suatu kondisi individu yang kurang dikenali secara pribadi yang dapat menciptakan kekaburan tanggung jawab yang membuat seseorang tidak merasa bersalah atas perbuatan salah yang telah dilakukannya) menjadikan orang agresif, sering mencuri serta merusak, kehilangan rasa tanggung jawab sosial. 
Menanggapi fenomena permasalahan komunkasi interpersonal yang dialami oleh individu, Vance Packard (dalam Budiman, 2010) menyatakan bahwa kemampuan komunikasi interpersonal dapat membantu seseorang untuk memperoleh informasi pengetahuan yang benar guna meningkatkan prestasi akademik, mengembangkan keterampilan dan membangun hubungan sosialnya secara efektif. Melalui komunikasi interpersonal, individu dapat mengungkapkan pesan yang diinginkan, dirasakan, dan dipikirkan terhadap orang lain dan kemudian dapat mempengaruhi proses pembinaan hubungan baik dengan orang lain, dan hal itu akan terjadi jika individu pelaksana komunikasi tersebut memiliki sikap asertif di dalam dirinya.

Pendidikan merupakan suatu proses yang mengarahkan siswa untuk menjadi seorang pribadi yang mandiri, cakap, kreatif, inovatif serta memiliki sikap tegas, jujur dan mampu menjalin komunikasi interpersonal dengan individu lainnya. Sesuai dengan konsep pendidikan nasional tersebut, kenyataan menunjukkan bahwa tidak sedikit siswa yang telah mencapai hasil belajar yang baik namun tidak mampu mengkomunikasikan hasil belajarnya dengan kata-kata secara memadai dan hal itu membuktikan bahwa siswa tersebut mengalami gangguan dalam keterampilan berkomunikasi. Fenomena masalah rendahnya kemampuan siswa dalam berkomunikasi di atas, Wahyuni, I dalam penelitiannya (2015) menyatakan bahwa siswa di SMA Negeri Aumbang Malang yang terdiri dari 62 siswa terdapat 48 siswa yang memiliki kemampuan komunikasi interpersonal yang tergolong rendah ketika diminta untuk menyatakan pendapat dan gagasannya di dalam proses pembelajaran di kelas.

Rendahnya kemampuan siswa dalam melakukan komunikasi interpersonal dapat diamati melalui perilaku yang ditampilkan ketika diskusi di dalam kelas, misalnya sulit menyatakan dan menerima pendapat yang berbeda, tidak mudah percaya terhadap orang lain, berteman atau berbicara hanya dengan teman tertentu saja. Semua sikap tersebut tentunya sangat mempengaruhi kondisi belajar menjadi menurun dan kehidupan sosialnya terganggu.

\section{REVIEW LITERATUR}

\section{Komunikasi Interpersonal}

Istilah komunikasi berasal dari bahasa latin yaitu communication,dan bersumber dari kata communis yang berarti sama makna. Dengan kata lain, mengerti bahasanya saja belum tentu mengerti makna yang dibawakan oleh bahasa tersebut. Jelas bahwa percakapan kedua individu dapat dikatakan komunikatifapabila kedua-duanya, selain mengerti bahasa yang digunakan, juga mengerti makna dari bahan yang diperbincangkan (Effendy, 2004). (Shannon dan Weaver dalam Cangara, 2007; Rahman, E. 2015;Purnama, S. 2016) mengemukakan bahwa komunikasi adalah bentuk interaksi manusia yang saling pengaruh mempengaruhi satu sama lainnya, sengaja atau tidak sengaja dan tidak terbatas pada bentuk komunikasi menggunakan bahasa verbal, tetapi juga dalam hal ekspresi muka, lukisan, seni, dan teknologi.

Manusia sebagai makhluk sosial membutuhkan interaksi sosial dengan masyarakat atau dengan individu lainnya.(Sihabudin, S. 2014;Suryanto2015) menyatakan bahwa berkomunikasi merupakan suatu keharusan bagi manusia untuk menjalin hubungan antara sesamanya.Selain itu, ada sejumlahkebutuhan manusia yang hanya dapat dipuaskan melalui komunikasi interpersonal.Komunikasi interpersonal pada dasarnya dapat dipahami sebagai salah satu bentuk komunikasi pribadi sehingga komunikasi interpersonal diartikan sebagai komunikasi yang terjadi antar individu secara tatap muka, dan memungkinkan setiap pelakunya menangkap reaksi orang lain secara langsung baik secara verbal maupun non verbal. Komunikasi interpersonal memiliki potensial guna menjalankan fungsi instrumental sebagai alat untuk mempengaruhi atau membujuk orang lain. Penggunaan kalimat dan alat indera dalam proses komunikasi dapat mempertinggi daya bujuk pesan yang dikomunikasikan kepada komunikan.

(DeVito2007;Whardani, F. 2016) menyatakan bahwa komunikasi dapat dipahami sebagai suatu proses penyampaian gagasan, harapan, dan pesan yang disampaikan melalui lambang tertentu, mengandung arti, dilakukan oleh penyampai pesan dan ditujukan kepada penerima pesan. Berdasarkan definisi komunikasi di atas, secara garis besar dapat ditarik kesimpulan bahwa komunikasi adalah penyampaian informasi dan pengertian dari seorang individu kepada individu lain. Komunikasi akan berhasil jika adanya pengertian antara kedua belah pihak.

Berdasarkan penjelasan diatas dapat disimpulkan bahwa komunikasi interpersonal adalah sebuah proses dan usaha individu atau kelompok dalam memberi pengaruh dengan menyampaikan informasi atau pesan yang dimaksud kepada individu lain baik secara verbal maupun nonverbal sehingga mendapat umpan balik dan terjadiinteraksi antara kedua pihak. 


\section{Ciri-Ciri Komunikasi Interpersonal}

Sesuai dengan pemikiran (Permata, S. 2013; Putranto, S. A., \&Lataruva, E. 2014)menjelaskan bahwa, komunikasi interpersonal pada hakikatnya adalah komunikasi antara komunikator dan komunikan. Dari konsep tersebut dapat dirumuskan bahwa komunikasi interpersonal adalah suatu proses interaksi yang dilakukan oleh dua orang atau lebih yang terdiri atas komunikan dan komunikator dan terjadi secara spontan.

Definisi di atas memberi gambaran bahwa ciri-ciri komunikasi yang perlu diperhatikan oleh komunikan dan komunikator dalam komunikasi agar proses komunikasi itu berjalan secara efektif, yaitu: (1) terjadi secara spontanitas dengan media utama adalah tatap muka, (2) tidak memiliki tujuan yang telah ditetapkan sebelumnya, (3) terjadi secara kebetulan di antara peserta yang identitasnya kurang jelas, (4) mengakibatkan dampak yang disengaja atau tidak disengaja, (5) kerapkali berbalas-balasan, (6) mempersyaratkan hubungan paling sedikit dua orang dengan hubungan yang bebas dan bervariasi, dan (7) menggunakan lambang-lambang yang bermakna.

Berdasarkan ciri-ciri komunikasi yang diuraikan di atas, dapat dikatakan bahwa seorang individu yang memiliki kemampuan komunikasi interpersonal yang baik akan menampilkan sikap dan perilaku yang positif, yaitu: (1) memiliki hubungan sosial yang erat dengan sesamanya, (2) mampu memelihara hubungan sosial dengan yang telah dibinanya, (3) memahami berbagai cara yang dapat digunakan dalam menjalin relasi dengan orang lain, (4) mampu menerima perasaan, pikiran, motivasi, perilaku dan cara hidup orang lain, (5) berpartisipasi dengan usaha-usaha kolaborasi dan memikul berbagai peran pemimpin yang baik, (6) mempersyaratkan hubungan paling sedikit dua orang dengan hubungan yang bebas dan bervariasi, (7) mampu berkomunikasi baik secara verbal maupun non verbal.

Selain itu, karakteristik yang berkaitan dengan prinsip komunikasi interpersonal meliputi berbagai dimensi dalam kehidupan manusia itu sendiri, yakni dimensi jasmaniah, sosial historis, psikologis dan kultural. Richard L. Weaver (dalam Budyatna, dkk., 2011)merumuskan karakteristik komunikasi interpersonal kedalamdelapan, yaitu: (1) melibatkan paling sedikit dua orang, (2) adanya umpan balik, (3) tidak harus tatap muka, (4) tidak harus bertujuan, (5) menghasilkan beberapa pengaruh, (6) tidak harus menggunakan kata-kata, (7) dipengaruhi oleh konteks, dan (8) dipengaruhi oleh kegaduhan.

Safaria(2005)mengungkapkan ciri-ciri individu yangmemiliki kecerdasan interpersonal yang tinggidan yangrendah, karakteristik anakyang memiliki kecerdasan interpersonal yang tinggi, yaitu:anak mampu mengembangkan dan menciptakan relasi sosial baru secara efektif, 2) anak mampu berempati dengan orang lain atau memahami orang lain secara total, 3) anak mampu mempertahankan relasi sosialnya secara efektifsehinggatidakmusnah dimakan waktu dan senantiasa berkembang semakin intim dan mendalam serta penuh makna, 4) anak mampu menyadari komunikasi verbal maupun non verbal yang dimunculkan orang lain, ataudengan kata lain sensitif terhadap perubahan situasi sosial dan tuntutan-tuntutannya, 5) anak mampu memecahkan masalah yang terjadi dalam relasi sosialnya dengan pendekatan win-win solution (sebuah teknik komunikasi negosiasi yang menempatkan kedua belah pihak dalam posisi menang) serta yang paling penting adalah mencegah munculnya masalah dalam relasi sosialnya, dan 6) anakmemiliki keterampilan komunikasiyangmencakupketerampilan mendengarkan, berbicara dan menulis secara efektif. Termasuk pula di dalamnya mampu menampilkan penampilanfisik (model busana) yang sesuai dengan tuntutan lingkungan sosialnya.

\section{Pentingnya Komunikasi Interpersonal}

Manusia menampilkan tingkah laku tertentu, saling mempengaruhi yang menimbulkan perilaku sosial tertentu yang mewarnai pola interaksi dalam komunikasi interpersonalnya.Rakhmat (dalam Suciati, 2015) menyatakan bahwa komunikasi dapat membantu pertumbuhan manusia dan komunikasi amat erat kaitannya dengan perilaku dan keadaan manusia. Menurut Cassagrande (dalam Riswandi, 2013) mengemukakan bahwa manusia berkomunikasi karena memerlukan orang lain untuk saling mengisi kekurangan dan membagi kelebihan, ingin terlibat dalam proses yang relatif tetap, mengantisipasi masa depan dan ingin menciptakan hubungan baru.

Berdasarkan beberapa pendapat di atas, dapat disimpulkan bahwa komunikasi interpersonal adalah sesuatu yang sangat penting bagi pembentukan hubungan untuk saling mengisi kekurangan dan membagi kelebihan dengan orang lain.

\section{Kriteria Komunikasi Interpersonal}

Suatu tindakan manusia dapat dikatakan rasional apabila memberikan informasi dalam komunikasi yang cukup jelas mengenai tujuan seseorang melakukan tindakan tersebut. Menurut Johnson (dalam Dharmayanti, 2013) individu haruslah memiliki empat keterampilan dasar dalam membangun komunikasi interpersonal, yaitu: 
(1) mampu saling memahami dan percaya satu sama lainnya, (2) mampu mengkomunikasikan perasaan dan pikiran secara tepat, (3) mampu saling memberi dan menerima dukungan, dan (4) mampu menyelesaikan bentuk-bentuk masalah yang mungkin muncul dalam komunikasi dengan cara konstruktif.

Selanjutnya, DeVito (2007) menyatakan bahwa ada lima kriteria untuk mewujudkan keterampilan komunikasi interpersonal yang efektif, aspek-aspek kemampuan komunikasi tersebut adalah: 1) Keterbukaan (openness)adalah mencakup keinginan untuk saling memberi informasi mengenai diri sendiri, keinginan untuk bereaksi secara jujur terhadap pesan yang disampaikan orang lain, dan bertanggung jawab terhadap perasaanperasaan yang dimiliki dalam arti tidak mengkambinghitamkan orang lain; 2) Empati (empathy)merupakan kemampuan untuk merasakan dan mengalami apa yang dirasakan orang lain yaitu mencoba merasakan dalam cara yang sama dengan perasaan orang lain. Keakuratan berempati meliputi sensitifitas untuk merasakan kejadian-kejadian saat ini dan mampu mengerti kata-kata yang diucapkan ketika komunikasi interpersonal berlangsung; 3) Dukungan (suportiveness)yang diperlukan dalam komunikasi interpersonal, meliputi empat aspek, yaitu: (1) descriptiveness, lingkungan yang deskriptif yaitu lingkungan yang tidak mengevaluasi orang secara evaluatif sehingga membuat orang cenderung menjadi defisit. Orang yang merasa dievaluasi akan malu mengungkapkan perasaan-perasaannya secara bebas dan merasakan terus-menerus dikritik, (2) spontanity, individu yang berkomunikasi secara spontan yaitu yang memiliki pandangan ke depan dan terbaik dalam mengungkapkan pemikirannya, (3) provisionalism, menjadi profesional berarti memiliki pemikiran yang terbuka (open mindedeness), bersedia menerima pandangan orang lain dan bersedia merubah posisi atau pandangannya jika memang diperlukan, (4) dukungan yang tidak terucapkan berupa gerakan-gerakan menganggukkan kepala, mengedipkan mata, dan tersenyum; 4) Kepositifan (positiveness)di dalam komunikasi interpersonal sekurang-kurangnya melalui dua jalan, yaitu berdasarkan sikap positif dan menghargai orang lain, terdiri dari tiga hal, yaitu: (1) perhatian yang positif terhadap orang lain yang sangat mendukung keberhasilan komunikasi interpersonal, (2) perasaan yang positif sangat bermanfaat untuk mengefektifkan kerjasama, dan (3) perhatian dan perasaan yang positif itu harus dikomunikasikan sehingga komunikasi interpersonal dapat terpelihara dengan baik; 5) Kesamaan (equality) terkandung unsur keinginan untuk saling bekerjasama dalam memecahkan masalah, hal ini terwujud dalam memandang ketidaksetujuan dan perselisihan di antara individu yang berkomunikasi, lebih sebagai usaha untuk memahami perbedaan yang ada, daripada memandangnya sebagai kesempatan untuk saling menjatuhkan.

\section{Faktor-Faktor yang Mempengaruhi Kemampuan Komunikasi Interpersonal Rendah}

Pada proses komunikasi interpersonal, individu tidak akan terlepas dengan hambatan-hambatan dalam menjalin hubungan antar individu. Salah satu hambatan dalam melakukan komunikasi interpersonal adalah seorang pribadi tidak mampu membina hubungan yang baik dengan orang lain, sementara komunikasi menuntut hubungan sosial manusia melibatkan dua unsur pribadi secara penuh di mana keterbukaan dan kejujuran sangat dibutuhkan.

Jalaludin (dalam Pramitha, 2015) merumuskan beberapa faktor yang mempengaruhi kemampuan komunikasi interpersonal yang bertolak dari tantangan internal maupun ekternal individu itu sendiri, yakni: 1) Rendahnya rasa percaya diri: kurang percaya diri adalah keinginan untuk menutup diri, orang yang memiliki rasa percaya dirinya rendah selalu menghindar dari kegiatan komunikasi, ia takut orang lain mengejek atau menyalahkannya; 3) Peka terhadap kritik: seorang pribadi yang peka terhadap kritikan dari sesamanya akan lekas marah, dan cenderung menghindar dari dialog terbuka dan bersikeras mempertahankan pendapatnya dengan logika yang keliru; 4) Responsif terhadap pujian: senang terhadap berbagai pujian yang diterima dari sesamanya, selalu mengeluh, mencela, dan meremehkan siapa dan apapun; 5) Bersikap hiperkritis: tidak sanggup memberikan penghargaan atau pengakuan pada kelebihan orang lain; 6) Cenderung tidak disenangi oleh orang lain: individu yang agresif baik secara verbal maupun non verbal dalammenanggapi pernyataan dari sesama; 7) Berpikir pesimis: seorang pribadi yang enggan bersaing dengan orang lain dan menganggap dirinya tidak berdaya; 8) Takut untuk melakukan komunikasi: menarik diri dari pergaulan, selalu berusaha menghindari komunikasi dan berbicara apabila terdesak.

\section{Proses Komunikasi Interpersonal}

Proses komunikasi interpersonal dapat dikatakan efektif apabila seorang individu memiliki tiga domain kompetensi dalam proses pembelajaran yakni kompetensi kognitif baik secara non verbal maupun verbal, kompentensi untuk berperilaku secara efektif dan keterampilan untuk membangunmotivasi dalam berpartisipasi dalam berkomunikasi. Morrisan (dalam Primasari, 2015) menggambarkan empat cara untuk mengetahui kemampuan komunikasi interpersonal individu, yaitu: (1) pengamatan objektif, (2) pengamatan subjektif, (3) laporan diri, dan (4) menerima laporan.

Selama terjadinya proses pengamatan objektif, individu diminta hanya menyampaikan informasi yang perlu saja sambil memeriksa proses dan isi informasi tersebut oleh sipengamat untuk melihat kemampuan individu dalam menyampaikan pesan atau informasi secara jelas, tegas dan jujur serta sebagai dasar kompetensi 
individu dalam proses komunikasi interpersonal. Proses pengamatan subjektif, individu yang menyampaikan pesan atau informasi diamati oleh seorang pengamat yang terlatih untuk melihat keterampilan individu dalam menyampaikan pesan dalam komunikasi interpersonal.

Laporan diri dan penerimaan terhadap laporan tersebut merupakan suatu pendekatan yang saling berhubungan. Individu diminta untuk dapat menilai atau membuat laporan diri tentang keterampilan dan kemampuan dirinya dalam proses komunikasi interpersonal yang dibangun. Selain itu, penerimaan terhadap laporan diri merupakan suatu pendekatan untuk mengajak individu mengenal, memahami, mengerti dan pada akhirnya dapat menerima laporan diri tentang kemampuan serta keterampilan komunikasi yang dimilikinya.

\section{Tujuan Komunikasi Interpersonal}

Manusia dengan segala masalah kehidupannya yang sangat kompleks berawal dari masalah komunikasi karena pada hakikatnya manusia adalah makhluk sosial yang selalu berinteraksi dengan sesama dan lingkungannya. Proses pematangan pribadi serta perubahan pola pikirnya sangat mempengaruhi perilakunya saat berkomunikasi dalam pengambilan suatu keputusan dengan berani dan tegas.Pada umumnya komunikasi dapat mempunyai beberapa tujuan.

Adaempat tujuan atau motif komunikasi yangdikemukakan oleh DeVito (2011) yaitu: menemukan, berhubungan, meyakinkan, dan bermain. Selain itu menurut Widjaja (2010) komunikasi yang dilaksanakan memiliki beberapa tujuan.Berikut ini tujuan yang dimaksudkan: 1) Supaya yang disampaikan itu dapat dimengerti; 2) Memahami individu lain; 3) Menggerakkan individu lain untuk melakukan sesuatu.

Berdasarkan penjelasan di atas dapat disimpulkan bahwa komunikasi itu bertujuan untuk mengharapkan pengertian, dukungan gagasan, dan tindakan. Artinya, bahwa setiap kali jika bermaksud mengadakan komunikasi sebaiknya perlu mengetahui apa yang menjadi tujuan, Misalny: 1) Apakah ingin menjelaskan sesuatu kepadapihak lain. Ini dimaksudkan supaya pihak lain mengerti dan dapat memahami apa yang maksudkan; 2) Apakah ingin supaya pihak lain menerima dan mendukung gagasan yang disampaiakan. Dalam hal ini tentunya cara penyampaian akan berbeda; 3) Apakah ingin supaya pihak lain tersebut mengerjakan sesuatu yang disampaikan.

\section{Hubungan Komunikasi Interpersonal}

Manusia sebagai penyandang makhluk sosial di muka bumi ini tidak dapat melepaskan dirinya dari jalinan relasi di antara sesamanya. Individu akan selalu mengadakan kontak sosial terhadap orang lain, bahkan sebagian besar dari waktu yang dimiliki digunakan untuk berkomunikasi. Everett Kleinjan (dalam Faudi, 2012) menegaskan bahwa komunikasi sudah bagian kekal dari kehidupan manusia seperti halnya bernafas, jadi sepanjang manusia yang ingin hidup maka ia perlu berkomunikasi.

Konsep komunikasi di atas menegaskan bahwa dengan menjalin hubungan melalui komunikasi, individu dapat membentuk pola pikirnya melalui level pengertian untuk menumbuhkan rasa persahabatan, memelihara kasih sayang, menyebarkan pengetahuan, dan melestarikan peradaban. Pada dasarnya komunikasi interpersonal terjadi karena hakikat individu itu sendiri yang suka berkomunikasi dengan individu lain, karena itu setiap orang selalu berusaha agar mereka lebih dekat satu sama lain.

Kegiatan komunikasi interpersonal tersebut dilakukan sebagai salah satu upaya untuk memenuhi kebutuhan kerjasama dengan orang lain sebab dengan kerjasama, proses komunikasi interpersonal akan berjalan dengan efektif. Berdasarkan perspektif psikologi, hubungan antar individu dijelaskan dalam teori kelekatan (attachment theory) yang dipelopori oleh Jhon Bowlby dengan asumsi bahwa perilaku pengasuhan yang merupakan konsep konstruksi relasi berpengaruh pada pola relasi antara individu. Proses terjadinya relasi, misalnya hubungan antara orang tua dengan anak terdapat ikatan emosi yang di dalamnya mengandung perasaan, pikiran dan perilaku.

\section{KESIMPULAN}

Berkenaan masalah komunikasi interpersonal dan dampak negatif yang terjadi, maka dapat terlihat bahwa peran guru BK atau konselor dalam meningkatkan komunikasi interpersonal siswa harus dioptimalkan lagi sehingga pelayanan BK lebih berdampak positif. Hal tersebut mengandung makna bahwa guru BK atau konselor harus mengerti dan memahami siswa, baik itu bakat, minat, potensi, maupun perkembangannya sehingga memberikan peluang bagi guru BK atau konselor untuk membantu siswa mengatasi kelemahan, hambatan, serta masalah yang dialaminya. Pemberian bantuan tersebut dapat berupa pelayanan yang dilakukan secara perorangan, kelompok, maupun klasikal dengan memanfaatkan media pembelajaran. 


\section{REFERENSI}

Budiman. (2010). Semiotika Komunikasi Visual. Yogyakarta: Penerbit Buku Baik.

Budyatna,M., \& Leila,M. (2011). Teori Komunikasi Antar Pribadi. Jakarta: Kencana Prenanda Media Grup.

Cangara, H. (2007). Pengantar Ilmu Komunikasi. Jakarta: RajaGrafindo Persada.

Cangara, Hafid. (2007). Pengantar Ilmu Komunikasi Edisi Revisi. Jakarta: Raja Garfindo Persad.

DeVito, J.A. (2007). The Interpersonal Communication Book. New York: Pearson Education.

DeVito, J.A. (2011). Komunikasi Antarmanusia. Terjemahan oleh Maulana, A. Jakarta: Karisma Publishing Group.

Effendy, O.U. (2004). Komunikasi: Teori dan praktek. Bandung: Remaja.

Fuadi, A. (2012). Hubungan Persepsi Pola Asuh Demokratis Orang Tua dengan Komunikasi Interpersonal antara Remaja dan Orang Tua (Doctoral dissertation, Universitas Muhammadiyah Surakarta).

Gunawati, R. (2005). Hubungan antara efektivitas komunikasi mahasiswa-dosen pembimbing utama skripsi dengan stres dalam menyusun skripsi pada mahasiswa program studi psikologi fakultas kedokteran universitas diponegoro (Doctoral dissertation, Universitas Diponegoro).

Permata, S. (2013). Pola Komunikasi Jarak Jauh antara Orang Tua dengan Anak (Studi Pada Mahasiswa FISIP Angkatan (2009) yang Berasal dari Luar Daerah). JURNAL ACTA DIURNA, 2(1).

Primasari, W. (2015). Pengelolaan kecemasan dan ketidakpastian diri dalam berkomunikasi studi kasus mahasiswa perantau UNISMA Bekasi. Jurnal Ilmu Komunikasi, 12(1).

Purnama, S. (2016). Makna Komunikasi Nonverbal Tradisi Api Jagau (Doctoral dissertation, Fakultas Ilmu Komunikasi Universitas Islam Bandung (UNISBA).

Putranto, S. A., \&Lataruva, E. (2014). Pengaruh Kepemimpinan, Komitmen Organisasi dan Komunikasi Interpersonal Terhadap Organizational Citizenship Behavior Anggota Rotaract Club Semarang (Doctoral dissertation, Fakultas Ekonomika dan Bisnis).

Rahman, E. (2015). Pengaruh Metode Bermain Peran (Role Playing) terhadap Aktivitas Komunikasi Antar Pribadi Siswa Kelas X SMA Muhammadiyah Kalirejo 2014/2015. Jurnal Majalah Kreasi STKIP MPL, $15(1)$.

Riwandi. (2013). Psikologi Komunikasi. Yogyakarta: Graha Imu.

Romli, K., \& Si, M. (2017). Komunikasi Massa. Gramedia Widiasarana.

Safaria, T. (2005). Interpersonal Intelligence: Metode pengembangan kecerdasan interpersonal anak.Yogyakarta: Amara Books.

Sihabudin, S. (2014). Komunikasi Antarbudaya Mahasiswa Asean di UIN Sunan Ampel Surabaya (Doctoral dissertation, UIN Sunan Ampel Surabaya).

Suciati. (2015). Kumunikasi Interpersonal. Yogyakarta: Persindo.

Suryanto. (2015). Pengantar Ilmu Komunikasi. Bandung: Pustaka Setia.

Tarigan, M. (2012). Komunikasi Interpersonal Kaum Lesbian di Kota Pontianak Kalimantan Barat (Doctoral dissertation, Upn Veteran Yogyakarta).

Ulfah, F. (2013). Pengaruh model pembelajaran kooperatif teknik two stay two stray terhadap kemampuan komunikasi matematika siswa.

Wahyuni, I. (2015). Penerapan Solution Focused Brief Therapy (Sfbt) untuk Meningkatkan Kemampuan Komunikasi Interpersonal Siswa Kelas X IPA 1 SMA Negeri 1 Mojosari. Jurnal BK UNESA, 5(2).

Whardani, F. (2016). Analisis Kemampuan Komunikasi Matematis Siswa Kelas VII MTs. Daarul Hikmah Pamulang pada Materi Segiempat dan Segitiga (Bachelor's thesis, Jakarta: FITK UIN Syarif Hidayatullah Jakarta).

Widjaja, H.A.W. (2010). Komunikasi: Komunikasi \& hubungan masyarakat. Jakarta: Bumi Aksara. 